\section{Renal Transplantation}

\section{in Identical Twins}

T. E. STARZL, M.D.

R. S. BRITTAIN, M.D.

O. G. STONNINGTON, M.D.

W. R. COPPINGER, M.D.

$\Lambda N \mathrm{~N}$

W. R. WADDELL, M.D.

DENVEF.
Since 1954, renal transplantation from one identical twin to another has been reported in 25 cases, 1, 8.12.15.15,18,22 of which 18 have been done by Muray and his assoriates 15 in Bos101, Inasmuch as such twins develop from the same fertilized ovmm, theit tisstes are senetically irlentical and consequently mutually acceptable for homografting. 5.13 the problems encountered with tissuc transplantation under these circumstances are essentially technical and concern details of procurement, transfer, and revascularization of the kidney.

Submitted for publication Nov. 5, 1962.

Markle Scholar and Assoriate Professor of Surgery (Dr. Starzl); Instructor in Surgery (Dr. Briltain); A ssociate Professor of Surgery (Dr. Stomington), Clinical Instructor in Surgery (1)r. Coppinger); Professor of Surgery (Dr. Warklell).

From the Departments of Medicine and Surgery, Enversity of Colorado Medical Center, The Denver Veterans Administration Hospital, and the Denver Clinic.

Aidrel by Grants A-3176 and A-6283 from the Inited States Jublic Health Service.
The present report is of a renal transplantation performed in March, 1962. The kidney was domated hy a healthy 27 -year-old man to his identical twin brother who suffered from terminal giomernlonophitis. In aring for these patients, some valriations were evolved from the operative wethoils previously standardized ly Murray, Merrili, and Tarrison, ${ }^{13.18}$ involving not only the removal but the preservation and reimplantation of the kidney. In addition, a syndrome of postoperative microscopic hematuria occurred in the recipient patient which, although seen in previous cases, ${ }^{10}$ has not been described in the literature.

\section{Report of a Case}

A 27-year-old white male was referred to the Denver Voterans Arministration IIospital on lieb. 6, 1962, in hypertensive ericis. In 1955 the patient had been medically evaluated because of bilateral costovertebral angle pain. There was no antecelent illuess. A diagno is of acute ame chronic glomentonephritis was made on the hasis of albuminuria, hematuria.

$$
\text { Vol. } 86, \text { April, } 196.3
$$


and mild hypertension. The symptoms resressed promply, and he had no further complaints until 1959. Ilowerer, a rombine urinalysis performed in 19.58 had reven'erl proteimmria, hematuria, and hyaline, and stamular casts.

In 1959 the patient first noticed intermittent ankle erema and casy fatigability. In September of 1960 , he was first seen by J). Thillip (larte of tenver, Colorato. This boul pressure was $160 / 104 \mathrm{~mm}$. Hig. Urine findings were unchanged. Blood urea nitrogen was $20 \mathrm{mg} \%$, creatimine $2.0 \mathrm{mg} \%$, total protein $5.5 \mathrm{gm}$.\% with $2.9 \mathrm{gm}$. of albumin. lle was placel on a low salt, low protein cliet ame treated with chlorothiazide (Diuril) and potassium chloride. On this regimen he became relatively asymptomatic, but by Norem. her of 1961 , the plasma creatinine had risen to $4.5 \mathrm{mg}$.\% $\%$, the blood urea nitrogen to 64 ma. $\%$; and the blood pressure to $210 / 140$ mm. Hs. In January of 1962 , the patient lereloped healaches, blurring of vision, increased irritability, and intermittent diarrhea.

On phrsical examination, his blood pressure was fouml to be $220 / 145 \mathrm{~mm}$. ITs pulsc 80, respirations 26 per minute, temperature $37.5 \mathrm{C}$. He was well oriented. The conjunctivas were pate. On funcluscopic examination there was bibateral arterial spasm, a few hame hemomhages, and early papilledema. There was slight pretibial eclema.

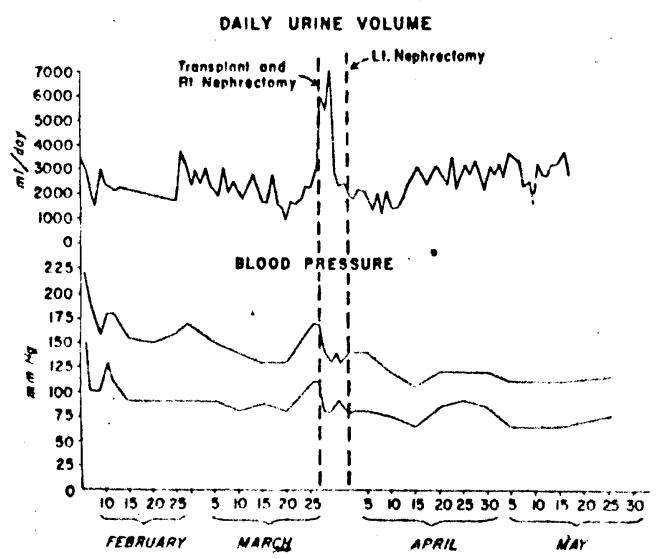

Fig. 1.-Bhod pressure and daily urinary volune for the 2 months precelling and the 2 months following renal transplantation.
Libomatory studies revealed a hematocrit of $36 \%$, himmolobin $12.4 \mathrm{gm} . \%$, white blood count 12,400, with 92 neutrophils. Seclimentation rate wats 38 . Blood urea nitrogen was $39 \mathrm{mg} . \%$, and creatinine $4.6 \mathrm{mg} \%$. Tota! protein was $5.25 \mathrm{gm} . \%$ with $2.75 \mathrm{gm}$. albumin. Serum electrolytes were: $\mathrm{CO}_{2}, 17$ mlir. per liter, chloricles $115 \mathrm{mliq}$. per liter, solium 144 mlicl. per liter, potassium 5.0 mlicl. per liter, calcium $9.5 \mathrm{mg} \% \%$, and phosphou us 5.2 mg. \%. Urine cultures were negative. Urinary protein for 24 hours was 4.3 gns. Creatinine clearance was 21.6 and 24.5 cc. per minute. $\triangle \mathrm{SO}$ titre was less than 125 Todd units. Urinary sodium was 39 :nlir. per liter and potassium $22 \mathrm{mlip}$. per liter.

The patient was treated with phenobarbital, hydrolazine ( $\Lambda_{\text {presoline }}$, chlorothiazide, and reserpinc, with a prompt clrop in blood pressure (ligg. 1). The eyegromul changes showed slow but definite resolution over the next few diays. Urinary output remained relatively constant at about 2,200 cc. claily (Fig. 1) Despite control of the patient's blood presisure, clinical deterioration was rapid. By March 23 the IBUN had risen to $104 \mathrm{mg} . \%$, and the creatinine to $5.3 \mathrm{mg} . \%$ (Fig. 2). J)uring lins period, his hematocrit had falled to $29 \%$. Transplantation was carried out on March 27, 1962.

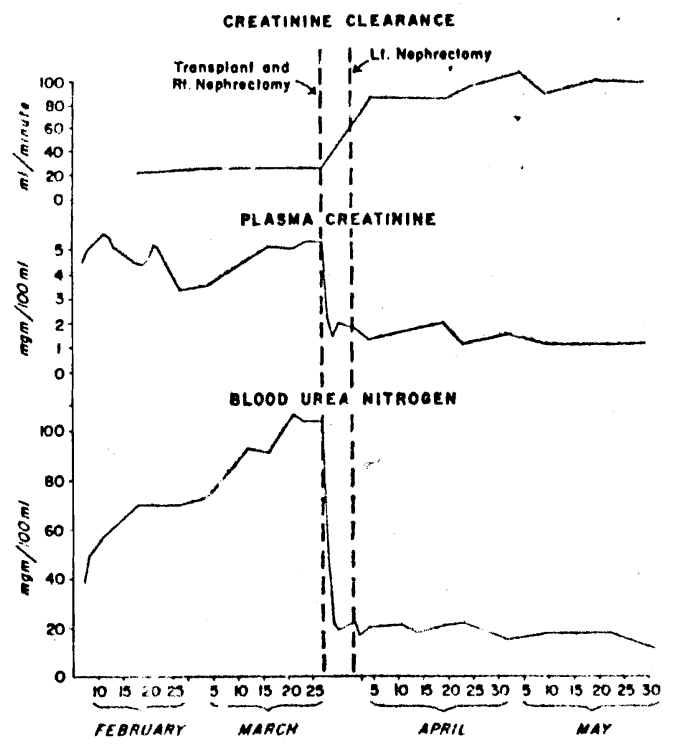

Jig. 2.-Creatinine clearance, plasma creatinine, and block turea nitrogen before and after remai transplantation.
Sindics on learued of the I'hillip (larke as September, Upon superfici lient rid not a largely becaust which had rest lumbar scoliosi $\Lambda$ pathologric their delivery $\mathrm{n}$ matchings wer irlentical for transfer of sp carried rut be Nov. 11, 1361. and liogrsy of revaled no evi

An intraven ticnt was norm creatinine was aortugram revi single renal ar

Opcration or tion was perfo cision hineath 1962, momler $\mathrm{g}$ $32 c^{\circ}$. The seol kirlney into the sure. Afler ope apcille was fro vessels. The ur ower the interic romoding areola of arewlar and teral peiste jur. wis beil whth th vaschlariations (lise 3). The were then cleane julnetiens with tl ara. The nrete felvis leaving th vascular furlicte nephreetenty wa given 2 mis. per

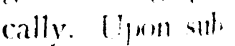
recipient romm, 1 Chanijed al thrir sels were lame

105 Staral at al. 
Studies on the Donor Patient.-Maving lea rned of the presence of a twin brother, itr. Thillip Clarke had initiated studies as carly as September, 1961, to establish Lwin illentity. Upon superficial examination, the dunor pat tient did not appear to be an ielentical twin. largely because of an orthopedic laformity which bad resulted in mother severe thoracolumbar scoliosis and a reduction in his height. $\Lambda$ pathologic record of the placenta foon their delivery was unobtainable. Blood-group) matchings were obtaned (Table) and were identical for the groups studied. Mutual transfer of split thickness skin grafts was carried out between the patients' thighs on Nov. li, 196i. Neither graft was rejecteri, and biopsy of both grafts on Feb. 19, 1962 revealed no evirlence of rejection.

An intravenous pyelogram in the donor patient was normal. BUN was $15 \mathrm{mg} \%$, and creatinine was $1.1 \mathrm{mg} \%$. A retrograde aortogram revaled good visualization of a single renal artery to each kidney.

Operation on Donor Patient.-The opera tion was performed through a left flank incision beneath the 12th rib on March 27. 1962, under general body hypothermia of $32 \mathrm{C}$. The scoliosis which projected the left kidney into the wound insured good exposure. After opening Gerota's fascia, the renal capsule was freed, taking care to ligate all vessels. The ureter was mobilized inferiorly over the pelvic brim, preserving the surrounding areolar tissue. A triangular section of areolar and fatty tissue between the ureteral pelvic function and the renai vessels was left with the specimen to insure proper vascularization of the upper ureter and pelvis (Fig. 3). The renal artery and renai vein were then cleaned off back to their respective junctions with the aorta and the inferior vena cava. The urcter was then transected in the pelvis, leaving the kirney attached only by its vascular peelicle. Ten minutes before the nephrectomy was completed, the paticnt was given $2 \mathrm{mg}$. per kilogram heparin systemicaliy. Upon subsequent command from the recipient room, the renal artery and vein were clamped at their proximal end, and the vesseis were transected. The kidney was re-

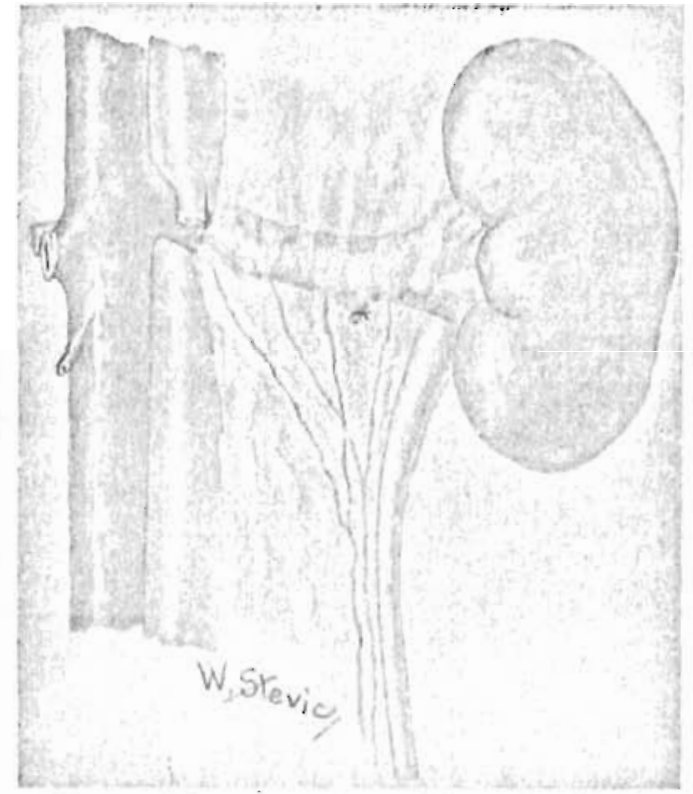

Fig. 3.-Diagran of donor kiciney showing prevention of pelve and wper ureteral blood supply.

moved to the recipient operating room, and the stumps of the vessels in the donor patient were closed with continuous No. 00000 arterial silk. Immediately after the nephrectomy had been completed, the donor patient was given a neutralizing dose of hexadimethrine bromicle (Polybrene). The wound was closed in layers without drainage, and rewarming carried out.

Operation on Recipicnt Patient-In the adjacent operating roon, the graft site was prepared in the right liac fossa of the recipient patient, employing a transverse lower abdominal incision which was extended into the right flank. A retroperitoneal plane of dissection was used. The common, external, and interna! iliac artery, and vein were mobilized. At this time it was determined that the internal ilrac (hypogastric) artery was partially occluted by extensive athermata, and it was decided at this time to implant the renal artery into the side of the common iliac artery. The precise location of the proposed arterial and venous anastomoses was selecterf, and instructions were then passed to the donor operating room to remove and bring in the kidney.

The donor patient's left kidney was then placed in the right iliac fossa so that its

Vol. 86, April, $1963 \quad 100$ 


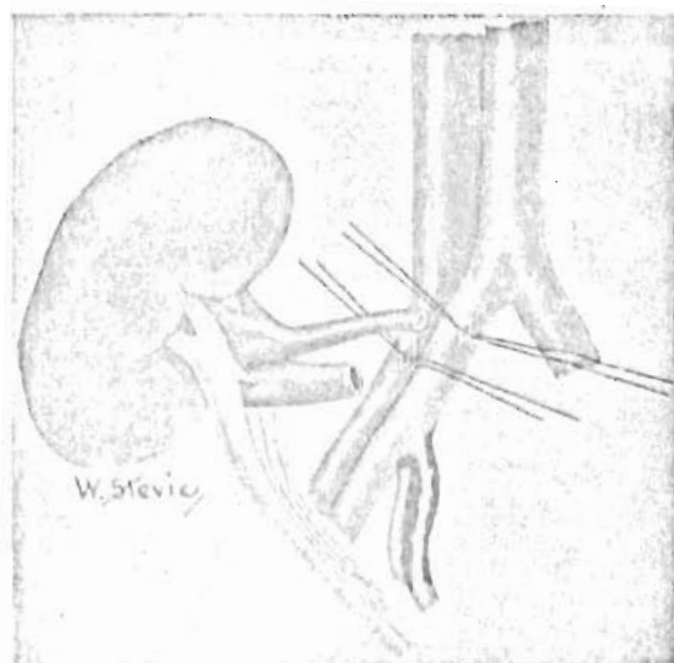

lig. 4-Donor kiney in recipient sitc. Note the reversed reiationship of the pedicle structures in the graft bet. End-to-side anastomoses were performed with both artery and vein.

fomer posterior surface was directed anteriorly, thus reversing the relationships of the renal pedicle (Fig. 4). An enci-to-side renai vein to common iliac vein anastonosis was performed using continuous No, 000000 arterial silk (Fig. 4). The end of the renal artery was next anastomosed to the side of the common iliac artery with a similar technique. The occluding vascular clamps vere then released, and prompt revascularization of the kidney was noted. The total ischemic period of the renat graft was 36 minutes.

Two humbed forty $\mathrm{mg}$. per kilogram of mannitol was administered intravenously at this time, and cight minutes later copious urine flow was noted. Ureterocystostomy was performed using the technique of Stevens and Marsiall ${ }^{21}$ as modifed by Paquin, ${ }^{20}$ in which a submticosal tumnel is combined with ureteral tip eversion (Fig, 5). The areterocystostomy was placel as far posteriorly as possible in orfer to minimize movement of the anastomosis with bladder filling. The graft was fixed in the right iliac fossa with capsular sutures. The right kidney was then removed through the same retroperitoneal incision without diffeulty. Bladter drainage was provided with a urethrai catheter. Two drains were left in the retroperitoneal space. A transfusion of $500 \mathrm{cc}$. blood was given.

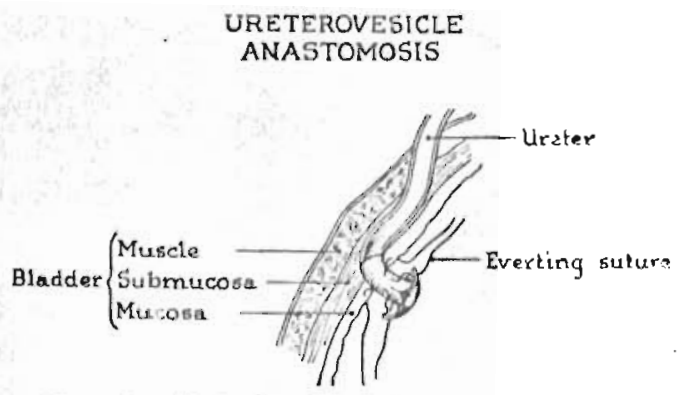

Fig. 5-Method of urelerecystostomy using methol of Panvin, employing combination of submocosal lumel and ureteral nippic.

Six days later, on Mareh 2, 1962, a left nephrectomy was performed through an anterior retroperitoneal approach.

Postoperalive Courst. Both patients recovered promptly from their surgical procedures. The lonor twin was discharged from the hospital 10 dinys after operation.

For tne first 3 days after transplantation, the recipient patient had a marked diuresis, averaging $6,100 \mathrm{cc}$, per day (Jig. 1). Urinary electrolytes during this perind were: sodium 80 to 100 mEq. per liter, potassium 10 to $11 \mathrm{mE}$. per liter, chorides 45 to 55 mEq. per liter. The urinary concentrations of creatiuine and urea during the dinesis were $38 \mathrm{mg} / 100 \mathrm{cc}$ and $490 \mathrm{mg} / 100 \mathrm{cc} \mathrm{re}-$ spectively. By the thind postoperative day, the urinary clectrolytes were: sodium 11 mEq. per liter, potassium $32 \mathrm{mEq}$. per liter, and chlorides $16 \mathrm{mEq}$. per lites, at which time the plasma concentrations of urea and creatinine were within nomal limits (Fig. 2). Subsequently in this patient's course the urinary concentration of clectrolytes fluctuated wirlely. Fluid therapy during the diuresis was based on six hourly deteminations of urinary volume and composition. Initially fluid and dectrolytes were replaced quantitatively. The cessation of dimesis corresponded to the period of urinary sodium conservation, starting on the third day, and fuil and electrolyte replacement was reduced accordingly. Diet was restmed on the fourh postoperative day.

There was no significant change in blood pressure following the transplantation, but beginning approximately one week after the

107 Staris el al. 
left nephreetoms, the recipient paticnt's blowel pressure droppere to within normal limits (ligr. 1), anel has remained at a normal level for the ensuing six months.

The clinical contse of the recipient patient after both operations wats quite benign exerpt for a transient feree of $10.3 \mathrm{l}$ immeriately after removal of his urethral catheter on the 12th day. Urinary culture at this time re. vealed a light groweth of Pseutomonas aeruginosa. Ife received a five day course of streplomycin (11/2 sme per day), and multiple cultures were subsequently negative. Ile was rlischarged to the medical service fontr wecks after transplantation and right nephrectemy, and three weeks after the left nephrectomy. Ite was discharged from the hospital on June 14, 1962, and has since remarried. He holds a full-time job as an accomtant.

Repeated minary function stulies have been done since operation. On $A$ prit $5,196 \%$. nine bays after transplantation and three days after removal of the remaining kidney, the one inour phenolsulfonpthatien excretion wis $35 \%$ and the creatinine clearance 84 ce. per minute. Multiple creatinine clearance de. terminations in the hospital (Jig. 2) anc! after discharge showed a slow increase, so that six monthe postoperatively it was $100 \mathrm{cc}$. per minne. Renal blood tlow, and tubular and glomerubar function will be the subject of a separate report. ${ }^{11}$ but these measures were higher than normal for a single kiciney.

The only disturhing postoperative feature was the presence of microscopic hematuria which was first noted immerliately after opcration and which has continued until the present time. The red bloorl cell commt in a 2 thour specinen ranged from 2 to 100 times that normally found. 'The heinaturia disall. peared or was greatly reduced when the pa. tient was confined to bet. The hematuria, in aklition to a low serum complement level, raised suspicion that the graft was develop. ing gromerulonepliritis. The patient was given a course of cortisone from May to August, 1962. The hematuria was minlluencel, and the cortisone the refore withlrawn.

\section{Comment}

A critical aspect of the preoperative evaluation for renal transplantation is the establishment of true identity between the domor and recipient twins. Although there have been reperts of prolonged survival of kirlney grafts in ncniclentical twins, the recipient patient requires irradiation or cytotoxic drugs to suppress the immune mecharism, and with all present techniques of host conclitioning the results are indifferent. ${ }^{10,17}$ In the patients described here, the difference in appeatance. sccondary tr an old orthopedic aleformity in the donor, male it at first difficult to believe that they wore irkentical twins. Irentity was proved by the demonstration that 18 blemel groups were the same in both patients (Tat be), and he the Bailure of rejection of the cross-skin grafts.

Another problem was the selection of the proper lidency for grafting. Socoliosio in the donor caused the leit kirlney to be displaced into an exposed and superficial position, potentially sulpect to future tratuma. For this reason, it was thought that use of the left kidney was manrlatory. Aortography. verformed one month before operation, showed that this kidney was supplied by a single artery of ample length and diancter. It is possible that anrtography should be more commonly performerl in the preoperative evaluation of the donor patients. In the first 12 cases of this igpe, information is available concerning the anatomy of the arterial supply. $3,7,8,12,18,2$ ' 'Two or more senal arteries to the donor bidney were found in four of

\begin{tabular}{|c|c|c|c|c|c|c|c|c|c|c|c|}
\hline & & & & & & & & \multicolumn{4}{|c|}{ Blood Groups } \\
\hline & Mnjor & $n h$ & c & $\mathrm{C}$ & $C *$ & 1) & $\mathrm{F}$ & e & $r$ & $\mathrm{~s}$ & $\mathrm{~s}$ \\
\hline Jonor & 0 & + & - & + & - & + & -- & + & t & + & + \\
\hline Rerloient & 0 & + & - & + & - & + & - & + & + & + & + \\
\hline
\end{tabular}




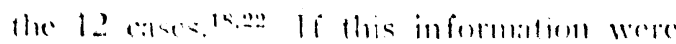

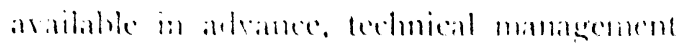

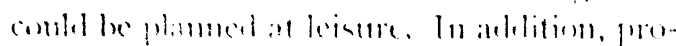

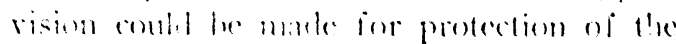

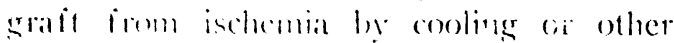
means, since the time for restablishment of the vascular supply is incevitably increased umler these circumstances.

In plamning the operation there was consilerable comernalomt the potential adverse eflects of the ischemic period (iuring transfer and revascularization of the graft. Jespite the experience in previosts cases of renal grafts that devascularization can be tolerated for as long as 90 minutes with eventual s.tisfactory restoration of function, the most rapid recovery in terms of immediate dimress and restoration of normal blood chemstries has been in cases of the briefest ischomia. The patients of Cohn ${ }^{6}$ and II Inne and Schiliing." in whom ischemia was limited to 22 and 45 minutes respectively har complete clear ing of azolemia in three days. When the de vascularized perionl had exceeded 45 minutes, azotemia has uswally pe:sisted for weeks, no months. Dinnesis from the transplant may be delayed. ${ }^{1 \times 22}$ In 1)osseter's well-studied rase, in which revascularization required $58 \mathrm{~min}$ ufes, there was serious depression of graft function which began wn the thirl postoperalive day and lasted for several weeks. It was felt by the atthors that this was a relaver result of ischemiat. Of partirular inferest is the difference in late sraft function in the patient reported by Bricker as comparel to the paticnt stulied by Guin and his associates." In the former case, in which the phaft was devascularized for so mintres, there were abmormalities in solium exereson une year a flei surgery following extracellubar Raiil vrolme altematoms. In the hatter case, in which the grafi was devascularized for 45 minues, sodimu excretion and all other functions were entirely nommal.

Tirins

\begin{tabular}{|c|c|c|c|c|c|c|}
\hline II & $F_{y}$ & I.eA & $J k^{*}$ & $J k^{b}$ & $\mathrm{Kp}^{n}$ & $K p^{b}$ \\
\hline- & + & + & + & + & - & + \\
\hline$\ldots$ & + & + & + & + & - & + \\
\hline
\end{tabular}

Staral at al.
In the present case it was hoped to prowide.

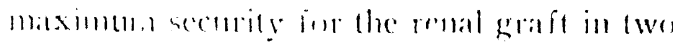
ways. The firet of these was lo instre maximum sperel of recomstimtion w the rasculat supply. This was achieved in a period of 3 fo minultes. Ariditional protection was obtained by subjecting the domor patient to moderate hypothermia, since it has been shown by Owens, ${ }^{1:}$ Pogardus, ${ }^{3}$ and many subsecpuent investigators that this adjuvant increases tolcrance to ischemia. Although hypothermia has not been employed in other cases of renal homotransplantation between iclentical twins, it has been described by Itamburger and his associates ${ }^{10}$ in homografts between noniclentical twins.

In arlition, the donor was given $2 \mathrm{mg}$. per kilogrum of heparin systemically a few minutes before the kidney was romover. This measure, designed to prevent clotting within the organ. was previously used by Cohn and his ascociates in a clinical case," administer. ing a neutralizing dose of hexalinsethrine inmediotely alter removal of the kidney. In exprimental animals it has been demonstrated by Mims 14 that the effective renal blood flow returns muris more rapilly when the graft has icen heparinized.

In dissecting the kidney in the donor patient, special care was directed to the preservation of the ureteropelvic blood supply. It is well known that long segments of nreter can be mubilized without adverse offects, providins that the ariventitia is retained. Prior to surecry, it was determined by calaver dicsections that the upier meter was constantly supplied by numerous small vessels which originater? fomm the renal artery and desecured in the fatly arenlar tissue hasted in the tramgun siac between the renal ves scls and the mper weter (fing 3). This region was therefore ourefully preserved, and the fatly and areoliti lissue was transplanted along with the kirhey.

In all previous cases of transplantation in ilentical twins, the principal arterial blemel supply has been restored by an end-to-end renal artery hyomastric artery anastomosis. In Creech's ase, the hypogastric artery was the site of severe atherosclerosic, and a pre- 
liminary endarterectomy was necessary."2 In our cisce, multiple atheromata made the hyposastric artery unsulable for use. Consequently, an alternative procedure was employed using an end-to-side anastomosis between the renal and the common iliac arteries. Mims 14 has studied the relative effectiveness of end-to-side versus end-to-end anastomosis in renal transplants in dogs. These authors fommd that with an enel-to-sicle anastomosis, the desree of compensatory byperplasia as well as the renal plasma flow were somewhat reduced. However, in our case there appeared to be no adverse func. tional effects from this variation in technique. Postoperative renal plasma flow and other functional tests were quite satisfactory, both immediately and for as long as sis, months postoperatively.

The method of implantation of the wreter into the blackler would appear to be important in terms of long-term success, since severil of the previously reported cases have had persistent urinary tract infections after operation. The method of implantation should provicle free urinary drainage, and prevent refux. In the presently reported case. Whe methorl of Sievens and Marshall 21 was employed as modified by laguin. ${ }^{20}$ A submucosal tumnel was fashioned, through which the ureter was brought. In addition, the tip of the rreter was folded back to form a nipple projecting into the interine of the batrler (Fige. 5). In our casc minary drainase was demonstratert to be mimpeded, and there was no pyclographic eviclence of regurgitation.

One of the most ilrealed late complications of renal transplantation, particularly in patients whese intial discase was ghomerulomephritis, has heen recurrence of the disense in the transplanted kirlney. ${ }^{18}$ When this has ocenred, the recurrent glomerulonephritis has rum an acederated course. There is stegerstive criflence that remonal of the discased kidlueys may help contravert this complication. ${ }^{18}$ The timing for removal of the recipient patient's own lirlneys has var. ied from seven days to six months. In our case, the recipient's right kidney was removed through the same retroperitomeal in- cision used for the transplantation. Jirom a technical print of view, this was casily accomplisherl. The second or left kidney of the recipient paticnt was removed six days later through a separate incision.

It has been noted on numerous occasions that a successful renal transplant provides a copious immerliate diuresis. A large part of this effect is probably attributable to the osmotic diuretic effect of the elevated plasma urea. In the present case, mannitol was given at the cime of transplantation in oreler to promote an inmediate liuresis. Whether this form of therapy is advisable is open to ruestion in view of recent studies which suggest that mannitol may complicate the postoperative course by causing sodium loss. ${ }^{2}$ In arlelition, it is cloubtful that mannitol acts in a manner different from that of endogrenous urca. Whether mannitol is or is not given, it is ciear that a precise recorel of not mily water but elecurolyte losses must be kept in order to treat rapid and potentially lethal fluid or electrolyte depletion eflectively.

The recovery of the recipicut patient from the two operative procedures was strpprisingly lenigan in view of his critically ill aml feeble combliton. One postoprerative finding which ocasioned consideralie anxiety was the carly development and subsefuent persistence of merosenpic hematuria. This was noted in the inmediate postepstative perios and continued for many months. $A$ striking feature of the hematuria was its almost complete disapfearance when the paticnt was confined to bed rest. This complication has not been previously elescriber in the literature, but it has been notice! by Marray. ${ }^{\text {B }}$ The exact medamish of the persistent hematuria is mot dear, but is it influenced by position. fomther information on this postoperative complication wombl appear to be important, maticularly in dilicrentiating it from the hematuria which might be antici. pated if recuirent glomerulonephritis supervenel. inasmmen as the therapy wombl be (puite different.

\section{Summary}

A successful case of renal hansplantation from one identical twin to another has been 
presemed. The matitions from previnusly cmplored fechminges have been disenssed.

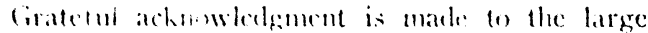
aroup of whe dians and surecens who participated in the are of the pationts before, during and after oreralion. These inclurled Dr. Gilhert Hermann, 1). Mhillip (lawhe. I)r. Richard Sanders, 1), Wonald Dickhaus, I)r. Joel Holmes, Dr. Nartin Ilutt, 1)r. (incton Meiklejohn, 1)r. Frank Jland, and Dr. William Rettberg.

Thumas l:. Starzl, M.1), Associate Professor of Surgery, University of Coloraclo Mcrlical Center,

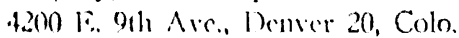

\section{Addendum}

The patient continues to be in good health with excellent renil function, 10 months after renal transpliantation.

\section{REPERENCES}

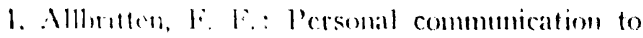
the athlor, sept. 7,1962 .

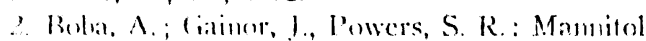

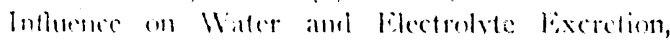
Surbery 5.2:18s, 196?.

3. Dingardus, (i. M., and Schlosser, K. J.: The Influence of Temperature mon Ischemic Kemal Damate. Surere 39:070, 1976.

4. Rricker, N. S. ; Cinihl, IV. R.; Roardan. I. B., and Mcrrill, i. P': limetional Capacity of a Denervated fommolraneplanted Kidney in an Ldemical Twin with Pantel Ohervations in the Donor, $J$. Clin. Invest. is:1364, 19.76.

5. lirown, 1. 13. Homorafting of Skin: With Repent of Suncess in lolentical Twins, Surgery 1: $5.8,10.3$.

6. Colm, k, ; Hurhelman, H.. Ir.; Yommg, I., and Holman, II. A. A Successful Case of Homotransplantation of the kidney Betwern ldentical Twins, Amer. I. Surg 102:344, 1961.

7. Hussctor, 1. B.; Mackinnon, K. I.; Luke, I. (.; Morkan, K. O., and Beck, J. C. : Krmal Transplantation Betwe.n Jelentical Twins, Jancet 2:572, 19(1).

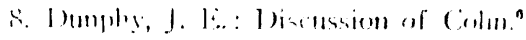

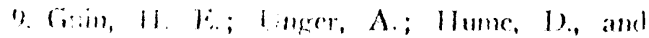
Schillinge I. : Iluman kenal Transplantation, I. Lab. (liir. Merl. $50: 1,1960$

10. Hamburger, J ; Vaysec, I.; Crosnicr, J.; Auvert, I ; Lalamme, C. M., and I Lopper, J., Ir.: Renal Fomotraneplantation in Man After Rarliation of the Recipicnt: lixperience with 6 Cases Since 1959, Amer. J. Med. $32: 854,1962$.

11. Hut:, M. I.; Holnes, J. H.; Clarke, P. J., and Dickliaus, D. W.: Unpublished data.

1.. Menville, I (r.; Schlegel, J. U.; Pratt, А. M., II, and Creccli, O., Jr. : IIman Kidncy Transplanlation in Thentical 'Twins, J. Urol, 85:233. 1961.

13. Morrill, I. I?.; Mutray, J. 1... ; Taurison, J. Jl, andi Cinild, IV. R. : Suecessful I Iomotransplantation of the Iluman Kidney Between Jdentical 'Twins, J.А. И. ^. 160:27\%, 1946.

1.1. Nims, M. M.: Tlemodynanics of Renal Transplantanion, J. (12ti. 86:4\%?, 1961.

15. Muray, I. L. I'ersomal communication to the itwher, Sent 1.3, 196?

16. Murray, 1. Fe Personal communication to the anthor. Arit, Ings

17. Muray, J. J..; Merrill, J. P.; Dammin, (i. J.; 1)aly, I. B.; Alexantre, G. W., and Harrisom. J. Jl. : Kielney Transplantation in Modified Recipiente, Ann. Surg. 156,:33\%, 1902 .

18. Murray, I. F.; Merrill, I. P., and Harrisen, I. I. : Kulney Tranchlantation Baiwen 7 l'airs of Tolntical fwins, Anw Surg. 148.343, 1958.

19. Ownn. I. C. ; Prevedel, A. F., and Swan, H. Protonger (ocelusion of the Thoracic Aorta bunge Hypothermia, A.M.A. Arch. Surg. 70:95, 1955.

20. Patuin, A. J.: Ureterovesical Anastomosis: The De: ription and Evaluation of a Techuicue, ]. Urol. $82: 573,959$.

21. Stcrens, A. R., and Marshall, V. F.: Reimpliuntation of the lireter into the Jbladeler, Surg. Givece (Obsted. $77.585,1943$

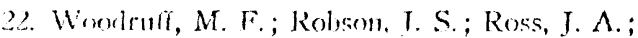
Nolan, B., anc Lambin, $\Lambda$. T. : Trancpiantation of a Kilney from an lelentical Twin, lancet $1: 1245$, 1961. 